\title{
Action of ethylene, 1-methylcyclopropene and silver thiosulfate in two developmental stages of potted ornamental pepper ${ }^{(1)}$
}

\author{
PAULA CRISTINA CARVALHO LIMA ${ }^{(2)}$; MILENA MARIA TOMAZ DE OLIVEIRA ${ }^{(3)}$; WELLINGTON SOUTO RIBEIRO(4); \\ LUCAS CAVALCANTE DA COSTA(2), FERNANDO LUIZ FINGER ${ }^{(5)}$
}

\begin{abstract}
The species of Capsicum genus have great genetic variability with enormous potential for marketing as ornamental potted plants. The exposure at ethylene induces various deleterious responses during plants life cycle, but there are few studies on how the ethylene affects early developmental stages of these ornamental plants. Thus, this study aimed to evaluate the effects of the application of ethylene and ethylene inhibitors, 1-methylcyclopropene (1-MCP) and silver thiosulphate (STS) in two early development stages (seedling or initial flowering) of potted ornamental peppers of the cultivars 'Calypso' and 'MG 302'. Cultivar 'MG 302' showed intermediate sensitivity to ethylene, while the cultivar 'Calypso' showed complete abscission of leaves when exposed to $10 \mu 1$ of ethylene for 48 hours in both development stages. Plants treated with 1-MCP showed similar durability to control for both varieties and developmental stages, and the treatment with 1-MCP + ethylene was beneficial only for 'MG 302'. STS was the most efficient substance in delaying the ethylene, wherein at stage 1 there was no leaf abscission and at stage 2 had much reduced leaf abscission occurred, regardless the cultivar. Treatment with STS + ethylene was efficient only at stage 1 for 'Calypso' and at stage 2 for 'MG 302'. According to the data, cultivars showed different levels of sensitivity to ethylene, 'Calypso' is very sensitive and 'MG 302' showed intermediate sensitivity. Regardless the cultivar, STS treatment significantly blocked the ethylene action in both development stages and the use of 1-MCP was less efficient.
\end{abstract}

Keywords: Capsicum annuum, senescence, ethylene action inhibitors.

\section{RESUMO}

Ação de etileno, 1-metilciclopropeno e tiossulfato de prata em dois estádios de desenvolvimento de pimenteiras ornamentais envasadas

As espécies do gênero Capsicum possuem grande variabilidade genética com enorme potencial para comercialização como plantas ornamentais de vaso. A exposição ao etileno induz várias respostas deletérias durante o ciclo de vida das plantas, mas há poucos estudos sobre como o etileno afeta estádios iniciais do desenvolvimento dessas plantas ornamentais. Portanto, este estudo objetivou avaliar os efeitos da aplicação de etileno e inibidores de etileno, 1-metilciclopropeno (1-MCP) e tiossulfato de prata (STS) durante dois estádios de desenvolvimento iniciais (plântulas e floração inicial) de pimenteiras ornamentais das cultivares 'Calypso' e 'MG 302'. A cultivar 'MG 302' apresentou sensibilidade intermediária ao etileno, enquanto a cultivar 'Calypso' apresentou abscisão completa das folhas quando exposta a $10 \mu 1$ de etileno por 48 horas em ambos os estádios de desenvolvimento. As plantas tratadas com 1-MCP apresentaram durabilidade semelhante ao controle para ambas as variedades e estádios de desenvolvimento, já o tratamento com 1-MCP + etileno foi benéfico apenas para 'MG 302'. STS foi a substância mais eficiente em retardar a ação do etileno, em que no estádio 1 não houve abscisão foliar e no estádio 2 houve abscisão foliar muito reduzida, independente da cultivar avaliada. O tratamento com STS + etileno foi eficiente apenas no estágio 1 para 'Calypso' e no estágio 2 para 'MG 302 '. De acordo com os dados, as cultivares apresentaram diferentes níveis de sensibilidade ao etileno, 'Calypso' é muito sensível e 'MG 302' mostrou sensibilidade intermediária. Independente da cultivar, o tratamento com STS bloqueou consideravelmente a ação do etileno em ambos os estádios de desenvolvimento e a utilização de 1-MCP foi menos eficiente.

Palavras-chave: Capsicum annuum, senescência, inibidores da ação do etileno.

DOI: http://dx.doi.org/10.14295/oh.v23i3.1036

(1) Received in 07/06/2017 and accepted in 08/08/2017

(2) Viçosa Federal University, Plant Biology Department, Viçosa-MG, Brazil. "Corresponding author: paula.c.lima@ufv.br.

${ }^{(3)}$ Ceará Federal University, Plant Production Department, Fortaleza-CE, Brazil.

(4) Paraíba State University, Agrarian and Environmental Science Center, Lagoa Seca-PB, Brazil.

${ }^{(5)}$ Viçosa Federal University, Plant Science Department, Viçosa-MG, Brazil.

Licensed by CC BY 4.0 


\section{INTRODUCTION}

Capsicum annuum species is considered the most cultivated and greater variability within the genus Capsicum (CARVALHO and BIANCHETTI, 2008). When evaluating the ethylene sensitivity within plant families, not all families have been found to have the same level of sensitivity between species or even among cultivars (MACNISH et al., 2011), because multiple receptors might be involved in contrasting responses in different tissues, as well as different developmental stages or different environmental stresses (IQBAL et al., 2017). Ethylene is a developmental regulator that operates in manifold physiological processes in all tissues throughout the plant life cycle (VAN DE POEL et al., 2015), regulates growth and senescence, depending on its concentration, timing of application and plant species (KHAN et al., 2008).

The use of ethylene inhibitors such as 1-methylcyclopropene (1-MCP) and silver thiosulfate (STS) help to control of ethylene action on ornamentals plants (SEGATTO et al., 2013). 1-MCP, is the most useful compound for this purpose among cyclopropenes, is nontoxic, stable at room temperature, active at relatively low concentrations providing protection for a long time (FINGER and BARBOSA, 2006). In addition, ion silver is a potent inhibitor of ethylene action by binding to ethylene receptors (KUMAR et al., 2009). Silver has better effect when applied as silver thiosulfate (STS) - $\left[\mathrm{Ag}\left(\mathrm{S}_{2} \mathrm{O}_{3}\right)_{2}^{-3}\right]$, because has more mobile and less phytotoxic than silver nitrate $\left(\mathrm{AgNO}_{3}\right)$ (VAN ALTVORST and BOVY, 1995). The use of inhibitors treatments affect at different levels the ethylene signaling pathway, reveals collectively an intricate network of interactions as exemplified by numerous studies of senescence in flowers reviewed in Ferrante et al. (2015).

During plant life, the transition from vegetative to reproductive stages and senescence is largely influenced by ethylene and its interplay with other plant hormones. These studies should be extended to different organs and development stages to deeply understand the intricate network affecting relevant agronomic traits such as yield, longevity and morphological appearance (IQBAL et al., 2017).

Currently there are underway studies about postproduction of ornamental potted peppers (LIMA et al., 2017; FINGER et al., 2015; SEGATTO et al., 2013), but little is known how ethylene affects early developmental stages, in which the plants can also be marketed. Besides, the production of seedlings can be considered as one of the most important stages in the cultivation of vegetables (SIPIONI et al., 2016) and can affect post-production. In general, exposure to ethylene during greenhouse production, shipping, and retailing can reduce the shelf life and garden performance of ornamental plants (JONES and LING, 2012).

This study aimed to evaluate the effects of the application of ethylene and ethylene inhibitors, 1-methylcyclopropene (1-MCP) and silver thiosulphate (STS) in two developmental stages of potted ornamental peppers of the cultivars 'Calypso' and 'MG 302'.

\section{MATERIAL AND METHODS}

Seeds from peppers of the cultivars Calypso and MG 302 (Capsicum annuum) were sown in flats with 36 single cells and transplanted to $760 \mathrm{~mL}$ plastic pots when the plantlets had four to five true leaves. Flats and pots containing one plantlet each were filled with commercial substrate containing pine bark, vermiculite, superphosphate, potassium nitrate and were fertilized at every week with $0.1 \mathrm{~g}$ (flats) and $10 \mathrm{~g}$ (pots) of NPK 10-10-10. Plants were grown in a greenhouse for about 35 days (seedling - stage 1 ) or about 50 days (initial flowering - stage 2).

Each variety was analyzed at two early developmental stages: seedlings and initial flowering. After the grown period in greenhouse, the pots were transferred to a room at $25 \pm 1{ }^{\circ} \mathrm{C}$, illuminated for 12 hours period with white fluorescent light (OSRAM, L40W/10S, USA) with intensity of $8-10 \mu \mathrm{mol} \mathrm{s} \mathrm{s}^{-1} \mathrm{~m}^{-2}$ during the experimental period (SEGATTO et al., 2013).

Pots were placed in a $90 \mathrm{~L}$ sealed chambers and were treated with $10 \mu \mathrm{L} \mathrm{L}^{-1}$ ethylene for 48 hours; fumigation with $1 \mu \mathrm{L} \mathrm{L}^{-1} 1-\mathrm{MCP}$ for 6 hours and fumigation with 1 $\mu \mathrm{L} \mathrm{L}^{-1} 1-\mathrm{MCP}$ for 6 hours followed by $10 \mu \mathrm{L} \mathrm{L}^{-1}$ ethylene for 48 hours according to the methodology described by Segatto et al. (2013). Plants were sprayed until runoff with $5 \mathrm{~mL}$ of $2 \mathrm{mmol} \mathrm{L}^{-1}$ STS and sprayed with $2 \mathrm{mmol} \mathrm{L}^{-1}$ STS followed by treatment with $10 \mu \mathrm{L} \mathrm{L}^{-1}$ ethylene for 48 hours according to the methodology described by Lima et al. (2017). The control plants were kept on the laboratory bench. Plants of all treatments were kept at $25 \pm 1{ }^{\circ} \mathrm{C}$ under white fluorescent light with intensity of 8-10 $\mu \mathrm{mol}$ $\mathrm{s}^{-1} \mathrm{~m}^{-2}, 60-65 \%$ relative humidity and watered when needed (FINGER et al., 2015).

Leaf abscission was determined at every three days by counting the total leaves during the whole period of shelf life, expressed in percentage compared to the initial leaf counting. The end of longevity occurred when there is $50 \%$ of leaf abscission and/or $50 \%$ yellowing of leaves (FINGER et al., 2015).

Degree of green color and flavonoids of the leaves was evaluated in three leaves in each plant: base, center and top, the average of determinations were considered. The chlorophyll content of leaves was determined by the chlorophyll index - Chl, the flavonoids index - Flav and nitrogen balance index - NBI were also determined, giving the reason CHL/FLAV, nitrogen deficiency and protein rate marker. All these variables were evaluated at every three days with the help of a leaf-clip portable meter Dualex ${ }^{\circledR}$ 4, design to measure chlorophyll, epidermal flavonoids and nitrogen balance index (FORCE-A, Université Paris Sud, 91893 ORSAY CEDEX, France). This instrument is used for non-destructive assessment of plant status, especially in regards to the simultaneous assessment of $\mathrm{Chl}$ and Flav on the same leaf spot, and was equipped with $6 \mathrm{~mm}$ diameter sensor in the measuring area and silicon photodiode detector (CEROVIC et al., 2012).

Pots were arranged in complete randomized block design with five replicates of one pot each. The average of the parameters analyzed were submitted to the standard 
error of the average $(n=5)$ and SigmaPlot software was used for data analysis and graph design.

\section{RESULTS AND DISCUSSION}

Regardless the stage of development, treatment with $10 \mu \mathrm{L} \mathrm{L}^{-1}$ ethylene for 48 hours induced total abscission of leaves for 'Calypso' (Figures 1A, 1C, 2A and 2B), while the 'MG 302' showed intermediate response to ethylene with about $88 \%$ abscission at third evaluation day for stage 1 and $44 \%$ abscission after treatment in stage 2 (Figures 1B, 1D, 3A and 3B). As previously shown by Segatto et al. (2013) and Lima et al. (2017) 'Calypso' and 'MG 302' in the post-production stage have different levels of sensitivity to ethylene, in which the 'Calypso' is highly sensitive and 'MG 302' showed intermediate response to treatment. On other hand, Edelman and Jones evaluated three accessions of Capsicum annum including 'Yellow Bell', 'California
Wonder 300', and 'Habanero Big Sun' and concluded that seedling ethylene sensitivity is lower than in the mature plant (EDELMAN and JONES, 2014).

Ethylene can trigger the senescence process, especially in the sensitive species, in any part of the plant and at any stage of leaf development. The exposure to ethylene induces premature senescence symptoms such as leaf yellowing, abscission, or desiccation/necrosis. Leaf senescence is activated at mature stage of leaf development when leaves are fully expanded, in the process three different stages can be identified: initiation, organization of degradation, and cell death processes (IQBAL et al., 2017).

$1-\mathrm{MCP}$ treatment was more efficient to the ethylene control, but showed high rate of accumulated leaf abscission, about $43 \%$ and $69 \%$ at sixth evaluation day (Figures 1A, 1C, 2C and 2D) and about 39\% and 57\% at nine evaluation day (Figures 1B, 1D, 3C and 3D) in stages 1 and 2 for 'Calypso' and 'MG 302', respectively.
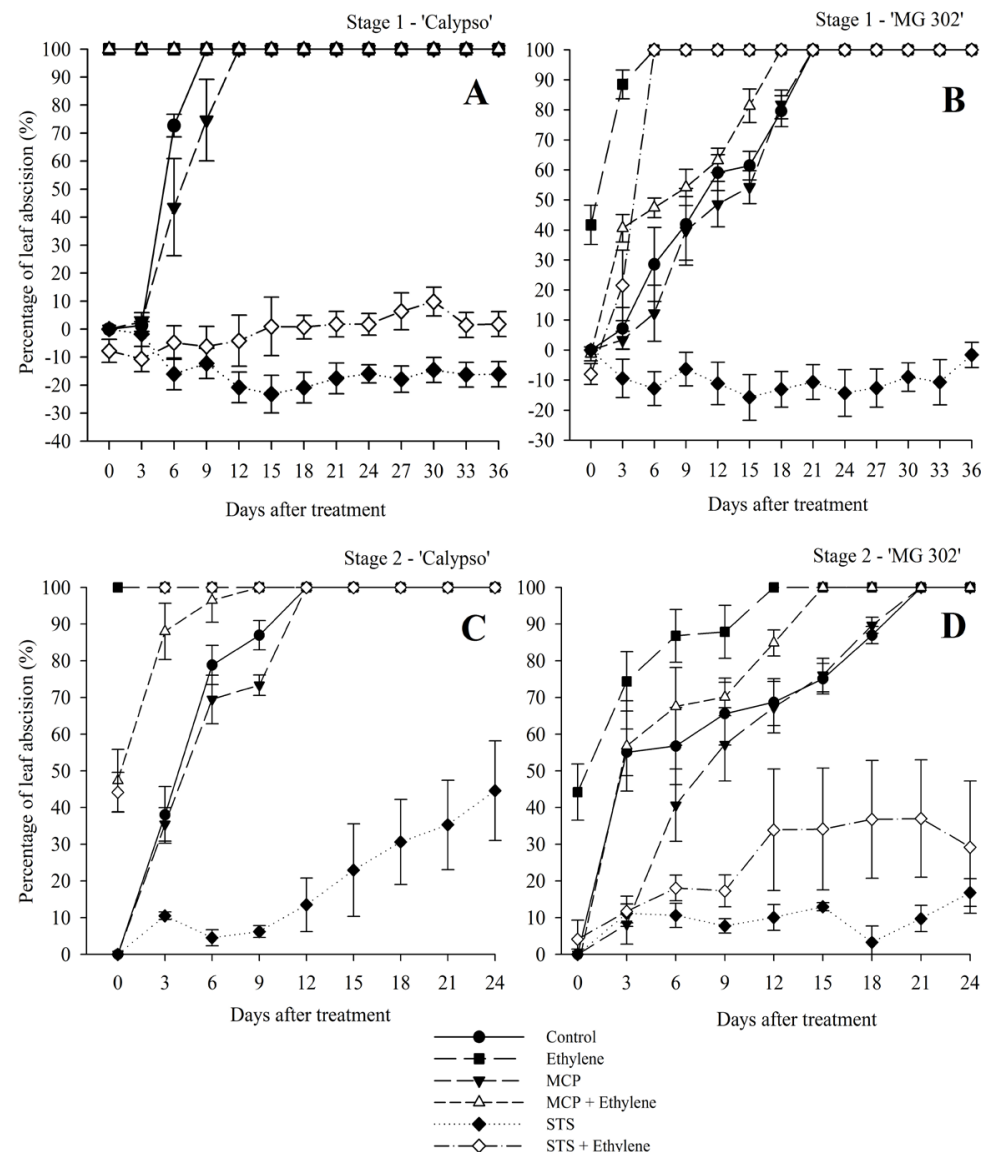

Figure 1. Accumulated abscission in leaves of development stage 1 - seedlings (A, B) and development stage 2 - initial flowering (C, D) of the ornamental pepper cultivars 'Calypso' and 'MG 302', after being treated with ethylene 48 hours, 1-MCP, 1-MCP + ethylene for 48 hours, STS and STS + ethylene for 48 hours and control. Values are a mean $( \pm$ standard error $)(n=5)$.

Treatment with 1-MCP + Ethylene was not efficient on 'Calypso', because showed complete leaf abscission after treatment on stage 1 , and in the stage 2 showed $96 \%$ leaf abscission at $6^{\text {rd }}$ evaluation day (Figures 1A, 1C, 2E and $2 \mathrm{~F}$ ); but was efficient on 'MG 302', having 54\% and $70 \%$ accumulated leaf abscission at nine evaluation day for development stages 1 and 2, respectively (Figures 1B, 1D, $3 \mathrm{E}$ and $3 \mathrm{~F}$ ). 

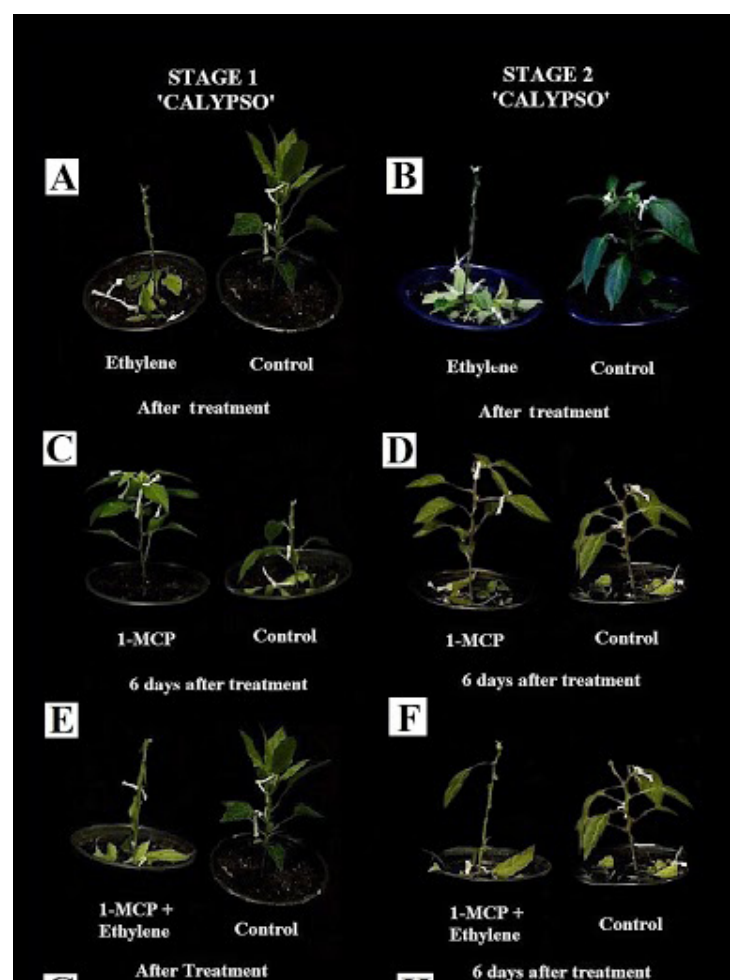

F

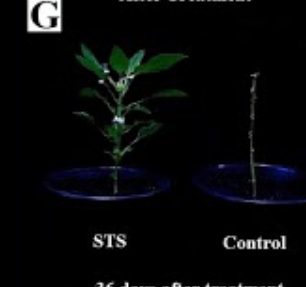

I

36 days after treatment

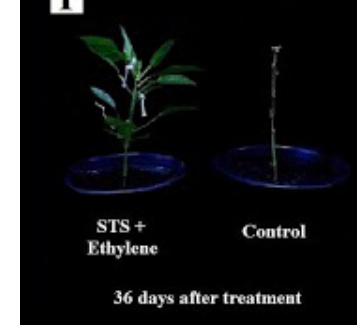

F

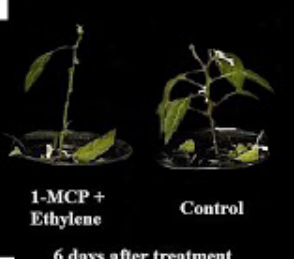

H

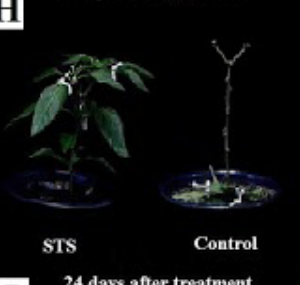

J

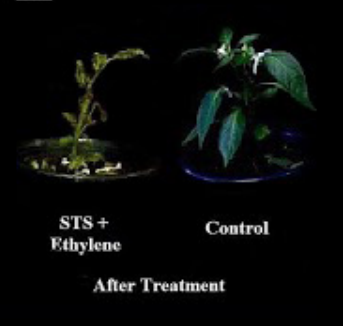

Figure 2. Appearance of the ornamental pepper 'Calypso' on development stage 1 (seedlings) and development stage 2 (initial flowering). A and B - treatment with ethylene compared to control; C and D - treatment with 1-MCP compared to control; E and F - treatment with 1-MCP + Ethylene compared to control; G and H - treatment with STS compared to control and I and J - treatment with STS + Ethylene compared to control. 

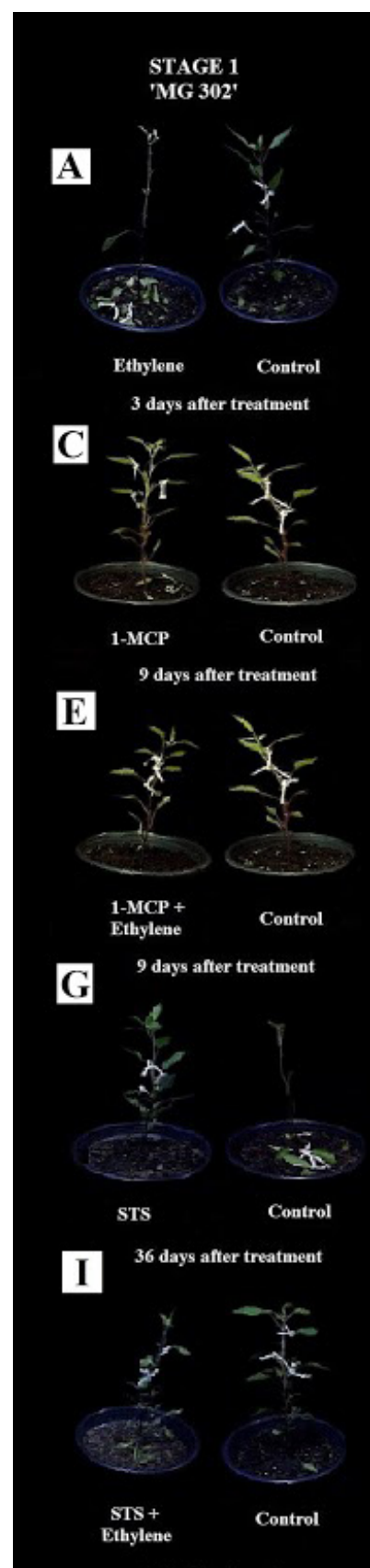

After Treatment
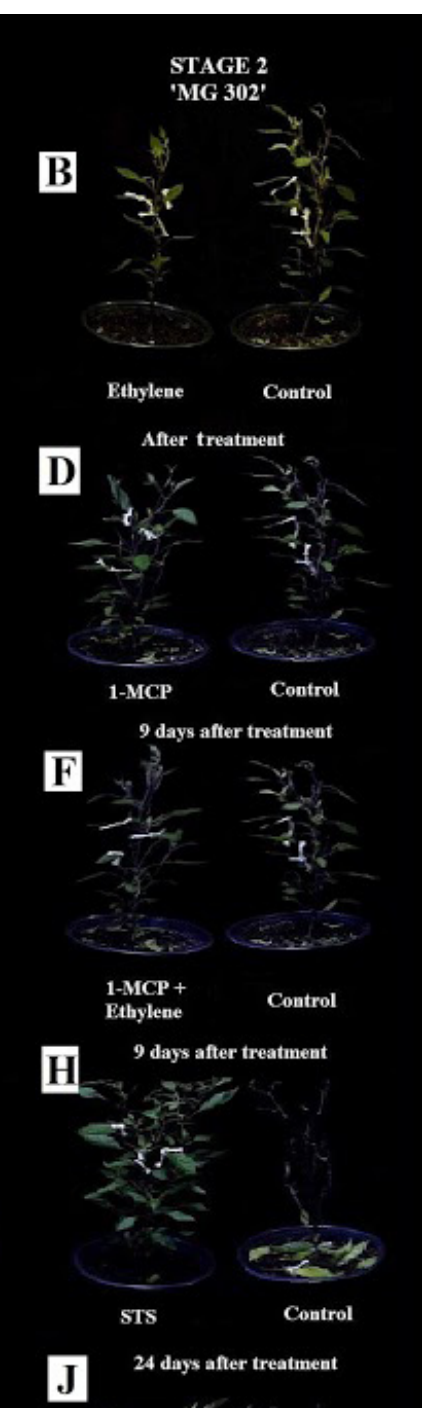

J

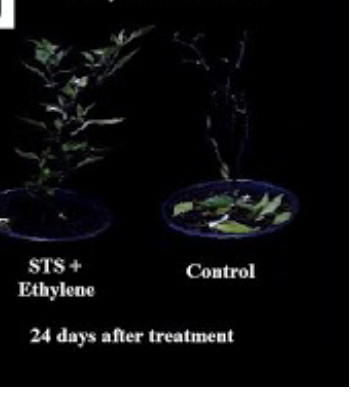

Figure 3. Appearance of the ornamental pepper 'MG 302' on development stage 1 (seedlings) and development stage 2 (initial flowering). A and B - treatment with ethylene compared to control; C and D - treatment with 1-MCP compared to control; E and F - treatment with 1-MCP + Ethylene compared to control; G and H - treatment with STS compared to control and I and J - treatment with STS + Ethylene compared to control. 
Similarly to this research, Lima et al. (2017) concluded that pretreatment with 1-MCP (with or without ethylene) was more beneficial in 'MG 302' at marketing stage.

If applied in mature plants, Finger et al. (2015) concluded that 1 -MCP treatment was effective in partially preventing the sudden fall of leaves in presence of exogenous ethylene in post-production of 'Calypso'. According to Phebe and Ong (2010), the effectiveness of 1-MCP varies with species and variety, development stages, and exposure temperature, concentration and duration. Moreover, 1-MCP may have contrary effects, either reducing or enhancing physiological disorders (ESTABLÉS-ORTIZ et al., 2016). Different reports suggest that the production of new ethylene receptors may be responsible for the loss of efficacy of $1-\mathrm{MCP}$ in blocking the perception of ethylene (PRANGE et al., 2005). Furthermore, 1-MCP may be metabolized in plants (HUBER et al., 2010) or ethylene and 1-MCP may bind with different affinities to different ethylene receptors (COOLS et al., 2011).

Plants treated with STS showed improved durability when compared with other treatments, at stage 1 there was no leaf abscission up to the thirty-six evaluation day in both varieties (Figures 1A, 1B, 2G and 3G), while in stage 2 there were $44 \%$ and $17 \%$ accumulated foliar abscission at twenty-fourth evaluation day in 'Calypso' and 'MG 302', respectively (Figures $1 \mathrm{C}, 1 \mathrm{D}, 2 \mathrm{H}$ and $3 \mathrm{H}$ ). At stage 1, treatment with STS + Ethylene was efficient in 'Calypso', because at the thirty-six evaluation day there was no leaf abscission, but induced phytotoxicity in 'MG 302' with expressive leaf wilt on third day (Figures $1 \mathrm{~A}, 1 \mathrm{~B}, 2 \mathrm{I}$ and $3 \mathrm{I}$ ), already at stage 2 , the treatment was efficient in 'MG 302' showing 29\% leaf abscission at twenty-fourth day, but caused phytotoxicity in 'Calypso' (Figures 1C, 1D, 2J and 3J). According Moura et al. (2010) the performance of the STS depends on the cultivar, stage of development and concentration used. Similarly, Lima et al. (2017) observed that STS is more effective in inhibits ethylene action in same evaluated cultivars at marketing stage.

During evaluations, there was complete flowers abscission and the plants have not reached subsequent development stages, there was only leaf emergence at the seedling stage, this fact is probably due to low irradiance (8-10 $\mu \mathrm{mol}$ photons $\mathrm{s}^{-1} \mathrm{~m}^{-2}$ ) the interior of the room, which reduced the photosynthetic process and by the increase of ethylene synthesis (SEGATTO et al., 2013). Buildup of ethylene in the atmosphere occurs mainly during transport and retail sales, which effects are increased by stresses (SÁ et al., 2008), which can promote or inhibit its development, altering the phenology and productive potential (TOMAZETTI et al., 2015). These responses to ethylene are influenced by environmental factors including light (ZHONG et al., 2012).

The Figures 4 and 5 shows the contents of chlorophyll (ICHL), flavonoid content (IFLV) and nitrogen balance index (IBN) in plants of 'Calypso' and 'MG 302'. 

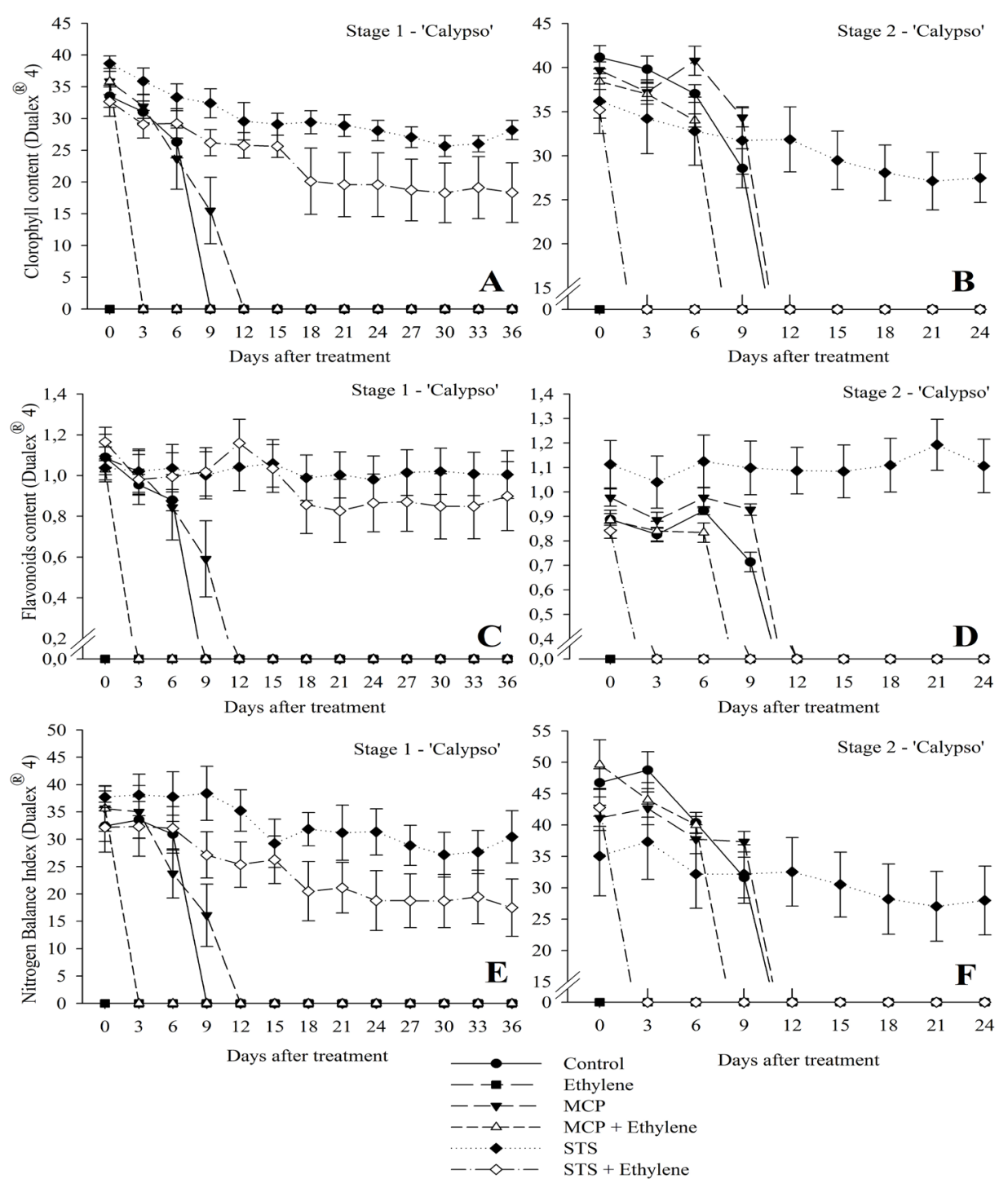

Figure 4. Chlorophyll index - Dualex ${ }^{\circledR} 4$ (A, B), flavonoids index - Dualex ${ }^{\circledR} 4$ (C, D) and nitrogen balance Index Duale $^{\circledR} 4$ (E, F) on development stage 1 - seedlings and development stage 2 - initial flowering of the ornamental pepper cultivar 'Calypso', after being treated with ethylene 48 hours, 1-MCP, 1-MCP + ethylene for 48 hours, STS and STS + ethylene for 48 hours and control. Values are a mean ( \pm standard error) $(n=5)$. 

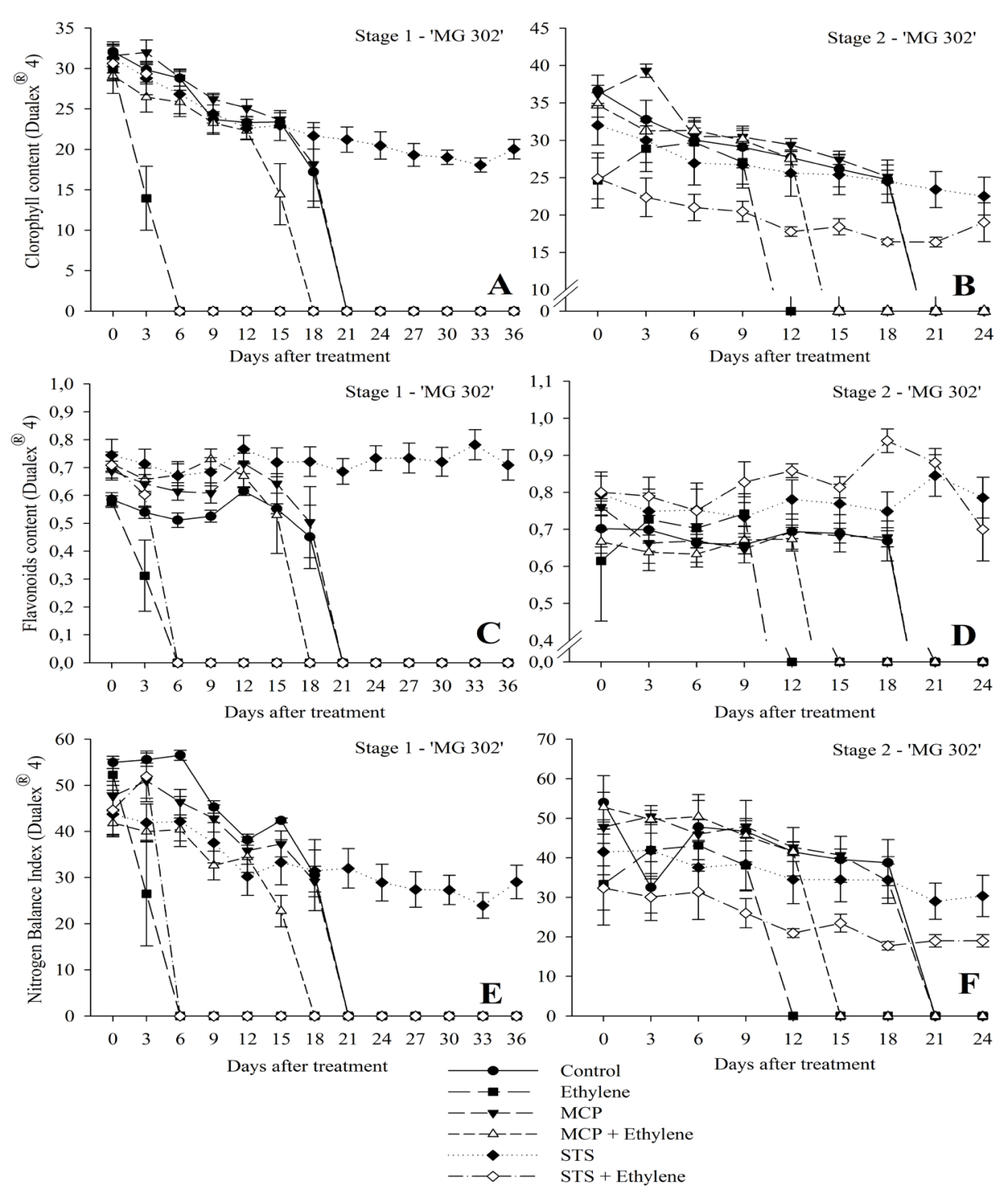

Figure 5. Chlorophyll index - Dualex ${ }^{\circledR} 4$ (A, B), flavonoids index - Dualex ${ }^{\circledR} 4(C, D)$ and nitrogen balance Index Dualex $^{\circledR} 4$ (E, F) on development stage 1 - seedlings and development stage 2 - initial flowering of the ornamental pepper cultivar 'MG 302', after being treated with ethylene 48 hours, 1-MCP, 1-MCP + ethylene for 48 hours, STS and

STS + ethylene for 48 hours and control. Values are a mean $( \pm$ standard error $)(n=5)$.

Generally, these parameters decreased during the survival of the plants. In 'Calypso' the most efficient treatments in stage 1 were STS and STS+ethylene (with lower leaf abscission), the variables showed respective decreases per day: $1.84 \%$ and $1.47 \%$ in the ICHL (Figure $4 \mathrm{~A}$ ); $0.15 \%$ and $1.43 \%$ in IFLV (Figure $4 \mathrm{C}$ ) and $0.58 \%$ and $1.29 \%$ in IBN (Figure 4E). At stage 2, the most efficient treatment was STS, showed decreases per day: $1.23 \%$ in ICHL (Figure 4B); $0.18 \%$ in IFLV (Figure 4D) and $0.65 \%$ in IBN (Figure $4 \mathrm{~F}$ ).

In 'MG 302', the most effective treatment at stage 1 was STS, with decreases per day: $1.78 \%$ in ICHL (Figure 5A); $0.39 \%$ in IFLV (Figure 5C) and $1.41 \%$ in IBN (Figure 5E). While the most efficient treatments at stage 2 were STS, STS+ethylene and 1-MCP, these treatments decreased per day respectively: $1.19 \%$;
$1.59 \%$ and $1.94 \%$ in ICHL (Figure $5 \mathrm{~B}$ ), $1.1 \% ; 0.44 \%$ and $0.09 \%$ in IFLV (Figure 5D) and $0.5 \% ; 1.0 \%$ and $1.92 \%$ in IBN (Figure 5F).

The decreases observed may be related to the fact of ethylene synthesis and sensitivity are enhanced during certain stages of plant development, as well as by a number of biotic and abiotic stresses, which stimulates chlorophyll destruction and yellowing, abscission and senescence of leaves (SALVEIT, 1999), because acts by converting chlorophyll a and $\mathrm{b}$ in chlorophyllide and phytol, resulting in loss of green color usually at concentration varying from 1 to $10 \mu \mathrm{L} \mathrm{L}^{-1}$ (FERRANTE and FRANCINI, 2006). The same authors mention that ethylene increases activity of chlorophyllase and oxidases responsible for chlorophyll degradation by regulating up their gene expression, in the presence or absence of light. 


\section{CONCLUSIONS}

Regardless of the development stages, varieties showed different levels of sensitivity to ethylene, 'Calypso' is very sensitive and 'MG 302' showed intermediate sensitivity, indicating that ethylene sensitivity at the early developmental stages correlated with ethylene sensitivity in marketing stage. Treatment with STS significantly blocked the ethylene in both development stages studied and that the use of 1-MCP was less efficient, probably due to the concentration of 1-MCP was used caused no effect in blocking the ethylene, the exposure time was inadequate or there was accelerated production of new ethylene receptor sites.

\section{ACKNOWLEDGEMENTS}

This research was supported in part by a grant from FAPEMIG (Research Support Foundation of the Minas Gerais State) and scholarships by CNPq (National Counsel of Technological and Scientific Development).

\section{AUTHORS CONTRIBUTIONS}

F.L.F. conceived the project, designed the work, analyzed the data, and wrote the article with contributions of all the authors; P.C.C.L. designed and performed experiments, analyzed the data, and drafted the article; M.M.T.O. performed experiments and analyzed the data; L.C.C. and W.S.R. revised and complemented the writing.

\section{REFERENCES}

CARVALHO, S.I.C.; BIANCHETTI, L.B. Botânica e recursos genéticos. In: RIBEIRO, C.S.C.; CARVALHO, S.I.C.; HENZ, G.P.; REIFSCHNEIDER, F.J.B. Pimentas Capsicum. Brasília: Embrapa Hortaliças, 2008. p.39-53.

CEROVIC, Z.G.; MASDOUMIER, G.; BEN GHOZLEN, N.; LATOUCHE, G. A new optical leaf-clip meter for simultaneous non-destructive assessment of leaf chlorophyll and epidermal flavonoids. Physiologia Plantarum, v.146, n.3, p.251-260, 2012. DOI: <http://dx.doi.org/10.1111 /j.1399-3054.2012.01639.x>

COOLS, K.; CHOPE, G.A.; HAMMOND, J.P.; THOMPSON, A.J.; TERRY, L.A. Ethylene and 1-methylcyclopropene differentially regulate gene expression during onion sprout suppression. Plant Physiology, v.156, n.3, p.1639-1652, 2011. DOI: <https:// doi.org/10.1104/pp.111.174979>

EDELMAN, N.; JONES, M.L. Evaluating ethylene sensitivity within the family solanaceae at different developmental stages. HortScience, v.49, n.5, p.628-636, 2014.
ESTABLÉS-ORTIZ, B.; ROMERO, P.; BALLESTER, A.R.; GONZÁLEZ-CANDELAS, L.; LAFUENTE, M.T. Inhibiting ethylene perception with 1-methylcyclopropene triggers molecular responses aimed to cope with cell toxicity and increased respiration in citrus fruits. Plant Physiology and Biochemistry, v.103, p.154-166, 2016. DOI: <https://doi.org/10.1016/j.plaphy.2016.02.036>

FERRANTE, A.; FRANCINI, A. Ethylene and leaf senescence. In: KHAN, A.N. Ethylene action in plants. Netherlands: Springer, 2006. p.51-67.

FERRANTE, A.; TRIVELLINI，A.; SCUDERI， D.; ROMANO, D.; VERNIERI, P. Post-production physiology and handling of ornamental potted plants. Postharvest Biology and Technology, v.100, p.99-108, 2015. DOI: $<$ https://doi.org/10.1016/j.postharvbio.2014.09.005>

FINGER, F.L.; BARBOSA, J.G. Postharvest physiology of cut flowers. In: NOUREDDINE, B.; NORIO, S. (Ed.). Advances in postharvest technologies for horticultural crops. Kerala: Research Signpost, 2006. p.373-393.

FINGER, L.F.; SILVA, T.P.; SEGATTO, F.B.; BARBOSA, J.G. Inhibition of ethylene response by 1-methylcyclopropene in potted ornamental pepper. Ciência Rural, v.45, n.6, p.964-969, 2015. DOI: <http:// dx.doi.org/10.1590/0103-8478cr20131386>

HUBER, D.J.; HURR, B.M.; LEE, J.S.; LEE, J.H. 1-methylcyclopropene sorption by tissues and cell-free extracts from fruits and vegetables: evidence for enzymic 1-MCP metabolism. Postharvest Biology and Technology, v.56, n.2, p.123-130, 2010. DOI: <https://doi.org/10.1016/j. postharvbio.2010.01.006>

IQBAL, N.; KHAN, N.A.; FERRANTE, A.; TRIVELLINI, A.; FRANCINI, A.; KHAN, M.I.R. Ethylene role in plant growth, development and senescence: interaction with other phytohormones. Frontiers in Plant Science, v.8, n.475, p.1-18, 2017. DOI: <http://dx.doi.org/10.3389/ fpls.2017.00475>

JONES, M.L.; LING, P. Preventing ethylene damage in the production greenhouse. Greenhouse Management, v.31, n.11, p.45-47, 2012.

KHAN, N.A.; MIR, M.R.; NAZAR, R.; SINGH, S. The application of ethephon (an ethylene releaser) increases growth, photosynthesis and nitrogen accumulation in mustard (Brassica juncea L.) under high nitrogen levels. Plant Biology, v.10, n.5, p.534-538, 2008. DOI: $<$ http://dx.doi.org/10.1111/j.1438-8677.2008.00054.x> 
KUMAR, V.; PARVATAM, G.; RAVISHANKAR, G.A. $\mathrm{AgNO}_{3-}$ a potential regulator of ethylene activity and plant growth modulator. Electronic Journal Biotechnology, v.12, n.2, p.1-15, 2009. DOI: <http://dx.doi.org/10.2225/ vol12-issue2-fulltext-1>

LIMA, P.C.C.; RIBEIRO, W.S.; OLIVEIRA, M.M.T.; COSTA, L.C.;FIGER, F.L.Ethylene, 1-methylcyclopropene and silver thiosulfate on the post-production of ornamental pepper. Ciência Rural, v.47, n.2, p.1-8, 2017. DOI: <http:// dx.doi.org/10.1590/0103-8478cr20151611>

MACNISH, A.J.; LEONARD, R.T.; NELL, T.A. Sensitivity of potted foliage plant genotypes to ethylene and 1-methylcyclopropene. HortScience, v.46, n.8, p.1127-1131, 2011.

MOURA, A.; MAPELI, A.M.; FINGER, F.L.; BARBOSA, J.G. Vida de vaso de inflorescências de Epidendrum ibaguense Kunth tratadas com inibidores de etileno. Revista Brasileira de Horticultura Ornamental, v.16, n.2, p.146-152, 2010. DOI: <http://dx.doi.org/10.14295/ rbho.v16i2.555>

PHEBE, D.; ONG, P.T. Extending 'Kampuchea' guava shelf-life at $27{ }^{\circ} \mathrm{C}$ using 1-methylcyclopropene. International Food Research Journal, v.17, p.63-69, 2010 .

PRANGE, R.; DANIELS-LAKE, B.; JEONG, J.C.; BINNS, M. Effects of ethylene and 1-methylcyclopropene on potato tuber sprout control and fry color. American Journal of Potato Research, v.82, n.2, p.123-128, 2005. DOI: <https://doi.org/10.1007/BF02853649>

SÁ, C.R.L.; SILVA, E.O.; TERAO, D.; SARAIVA, A.C.M. Métodos de controle do etileno na qualidade e conservação pós-colheita de frutas. Fortaleza: EMBRAPA Agroindústria Tropical, 2008. 36p.
SALVEIT, M.E. Effect of ethylene on quality of fresh fruits and vegetables. Postharvest Biology and Technology, v.15, n.3, p.279-292, 1999. DOI: <https://doi.org/10.1016/ S0925-5214(98)00091-X>

SEGATTO, F.B.; FINGER, F.L.; BARBOSA, J.G.; RÊGO, E.R.; PINTO, C.M.F. Effects of ethylene on the post-production of potted ornamental peppers (Capsicum annuum L.). Acta Horticulturae, v.1000, p.217-222, 2013. DOI: <https://doi.org/10.17660/ActaHortic.2013.1000.28>

SIPIONI, M.S.; FIRMINO JÚNIOR, J.L.; DIAS, P.H.R.; STEINER, F. Paclobutrazol and cattle manure use improves the quality of pepper seedlings. Scientia Agraria Paranaensis, v.15, n.3, p.332-337, 2016. DOI: <http:// dx.doi.org/10.18188/1983-1471/sap.v15n3p332-337>

TOMAZETTI, T.C.; ROSSAROLLA, M.D.; ZEIST, A.R.; GIACOBBO, C.L.; WELTER, L. J.; ALBERTO, C.M. Fenologia e acúmulo térmico em videiras viníferas na região da Fronteira Oeste do Rio Grande do Sul. Pesquisa Agropecuária Brasileira, v.50, n.11, p.10331041, 2015. DOI: <http://dx.doi.org/10.1590/S0100204X2015001100006>

VAN ALTVORST, A.C.; BOVY, A.G. The role ethylene in the senescence of carnation flowers, a review. Plant Growth Regulation, v.16, n.1, p.43-53, 1995. DOI: $<$ https://doi.org/10.1007/BF00040506>

VAN DE POEL, B.; SMET, D.; VAN DER STRAETEN, D. Ethylene and Hormonal Cross Talk in Vegetative Growth and Development. Plant Physiology, v.169, n.1, p.61-72, 2015. DOI: <https://doi.org/10.1104/pp.15.00724>

ZHONG, S.; SHI, H.; XUE, C.; WANG, L.; XI, Y.; LI, J.; QUAIL, P.H.; DENG, X.W.; GUO, H. A molecular framework of light-controlled phytohormone action in Arabidopsis. Current Biology, v.22, n.16, p.1530-1535, 2012. DOI: <https://doi.org/10.1016/j.cub.2012.06.039> 